by burning (just as many others) are carried to Britain and maintained. This factor, together with those described above, provides a better explanation of burning as a method of suicide than suttee.

RAMAMOHAN VeLURI

VINCENT T. GREENE

Department of Psychological Medicine

James Connolly Memorial Hospital

Blanchardstown

Dublin 15, Ireland

\section{The first case of battle hysteria?}

SIR: Patton (Journal, February 1981, 138, 180-181) described an early case of battle hysteria which occurred during the Peninsular War (1808-1814) in a soldier who was the author's great grandfather.

I would like to report an earlier case, recorded well before the advent of modern explosives, which occurred in 490 BC at the Battle of Marathon, and was reported by the Greek historian Herodotus (1954): "Epizelus, the son of Cuphagorus, an Athenian soldier, was fighting bravely when he suddenly lost the sight of both eyes, though nothing had touched him anywhere - neither sword, spear, nor missile. From that moment he continued blinded as long as he lived. I am told that in speaking about what happened to him he used to say that he fancied he was opposed by a man of great stature in heavy armour, whose beard overshadowed his shield, but the phantom passed him by and killed the man at his side."Herodotus does not tell us whether Epizelus had post-traumatic stress disorder as defined in the DSM-III-R (American Psychiatric Association, 1987), but he does give a life-time follow-up by indicating that Epizelus was blind for the remainder of his life.

Charles J. Hudson

Schoharie County Medical Health Center

County Office Building

PO Box 160, Schoharie

New York 12157

\section{Reforences}

American Psychiatric Assoctation (1987) Diagnostic and Statistical Manual of Mental Disorders (3rd edn, revised) (DSM-III-R). Washington, DC: APA.

Herodotus (1954) The Histories (ed. A. R. Burn). Harmondsworth: Penguin.

\section{Multiple personality disorder}

SIR: I would like to comment on two recent letters regarding multiple personality disorder (MPD). Coons (Journal, March 1990, 156, 448-449) states that "over 700 scientific articles, chapters, books, etc, have appeared on MPD, and that it was first recognised as a diagnosis in the DSM-III". Unfortunately, in a field like psychiatry, what is scientific to one may not be so to another. Furthermore, with all due respect to DSM-III, it tries to accommodate all kinds of psychiatric diagnosis and theories around the world, and as far as I am concerned, just because MPD is listed in the DSM-III, it does not necessarily become a scientific clinical entity.

Ross (Journal, March 1990, 156, 449) states that: "if all individuals admitted to an acute care adult psychiatric in-patient unit in Britain or South Africa were screened with the Dissociative Experiences Scale, I predict that about $15 \%$ would score above 30 . Of these individuals one-third would meet DSM-III$\mathbf{R}$ criteria for MPD on the Dissociative Disorders Interview Schedule and one-third would have another dissociative disorder." Thus, according to him we can deduce that $5 \%$ of all psychiatric admissions in Britain or South Africa will carry DSM-III-R diagnoses of MPD and another 5\% would have "another dissociative disorder". Considering the fact that the majority of psychiatrists have never seen or diagnosed a case of MPD on both sides of the Atlantic, I find these figures and predictions incredible.

Suite 251,

Lal Fernando

\section{Metropolitan General Hospital \\ 1995 Lens Avenue \\ Windsor, Ontario N8W IL9}

\section{Accurate description of ethnic minorities}

SIR: It is disappointing that in a special cross-cultural edition of the Journal, Milner \& Hayes (Journal, March 1990, 156, 438-440) employ the term 'second generation Jamaican' to describe the subject of their case report. This description implies that either the subject is a second generation immigrant in Britain or that three generations ago the family were not Jamaican.

Clearly this is an inaccurate description. Perhaps it is now time to describe as accurately as possible members of various ethnic minorities when writing scientific reports. May I suggest the term British Afro-Caribbean to describe people born in Britain of Afro-Caribbean ethnic origin. A Jamaican AfroCaribbean would describe a Jamaican immigrant in Britain.

\section{Department of Psychiatry}

O. JunAID

University Hospital and Medical School

Clifton Boulevard

Nottingham NG7 2UH 